\title{
PEMBAHARUAN HUKUM DI DALAM PERJANJIAN PERKAWINAN
}

\author{
Jamaluddin \\ Universitas Pamulang (UNPAM) \\ Jl. Surya Kencana No. 1 Pamulang Tangerang Selatan
}

\begin{abstract}
Marriage Agreement has been regulated in Law Number 1 of 1974 specifically article 29. Marriage Agreement is the right of each party to enter into a marriage agreement. The background of entering into an agreement is their respective rights. With the holding of the Marriage Agreement there is legal certainty about what was promised by them to do a legal action against what was promised. After the decision of the Constitutional Court Number 69 / PUU-XIII / 2015, the Marriage Agreement which can only be made by prospective husbands and future wives before the prenuptal agreement, through legal renewal, can be made by husband and wife after the marriage takes place.
\end{abstract}

Keywords: Engagement, Marriage, Legal Reform

\begin{abstract}
Abstrak
Perjanjian Perkawinan telah diatur dalam Undang-Undang Nomor 1 Tahun 1974 khususnya pasal 29. Perjanjian Perkawinan adalah hak masing-masing pihak untuk mengadakan perjanjian perkawinan. Latar belakang mengadakan perjanjian adalah hak mereka masing-masing. Dengan diadakannya Perjanjian Perkawinan terdapat kepastian hukum terhadap apa yang diperjanjikan oleh mereka untuk melakukan suatu perbuatan hukum terhadap apa yang diperjanjikan. Setelah putusan Mahkamah Konstitusi Nomor 69/PUU-XIII/2015, Perjanjian Perkawinan yang semula hanya dapat dibuat oleh calon suami dan calon istri sebelum perkawinan (prenuptal agreement), melalui pembaharuan hukum, dapat dibuat oleh suami istri setelah perkawinan berlangsung.
\end{abstract}

Kata Kunci: Perikatan, Perkawinan, Pembaharuan Hukum

\section{A. Pendahuluan}

Dalam Pasal 29 UU No. 1 Tahun 1974 Tentang Perkawinan disebutkan bahwa perjanjian perkawinan dibuat sebelum atau pada saat perkawinan berlangsung dan mulai berlaku sejak perkawinan dilangsungkan. Perjanjian perkawinan yang dibuat tidak boleh bertentangan dengan agama, kesusilaan dan batas-batas hukum. ${ }^{1}$

Dalam parkateknya perjanjian perkawinan lebih kepada harta kekayaan, sehingga harta kekayaan dalam suatu perjanjian perkawinan dijadikan sebagai objek dalam perjanjian. Karena harta kekayaan

\footnotetext{
${ }^{1}$ Undang-Undang No. 1 Tahun 1974 Tentang Perkawinan
} 
sebagai objek, maka berdasarkan ketentuan dalam UU No. 1 Tahun 1974 bahwa terdapat perbedaan harta yaitu harta bawaan dan harta bersama. Meskipun hal itu berbeda dengan Pasal 119 Kitab Undangundang Hukum Perdata (KUHPerdt), yang menyebutkan bahwa harta perkawinan menjadi persatuan secara bulat harta kekayaan dalam perkawinan. Tetapi dalam KUHPerdt mengecualikan jika terjadi perjanjian perkawinan. ${ }^{2}$

Perjanjian perkawinan belum merupakan lembaga hukum yang terbiasa dilakukan di masyarakat, yang semula hanya merupakan lembaga hukum khusus bagi anggota masyarakat Indonesia yang tunduk pada KUHPerdt, tetapi dengan semakin meningkatnya angka perceraian, keinginan orang untuk membuat perjanjian perkawinan semakin bertambah, karena biasanya pasangan suami istri yang bercerai akan meributkan pembagian harta perkawinannya. ${ }^{3}$

Dalam UU No. 1 Tahun 1974 Tentang Perkawinan disebutkan perjanjian perkawinan, di mana usia UU No. 1/1974 ini telah mencapai usia lebih 40 tahun, dan seyogianya harus segera dilakukan pembaharuan-pembaharuan. Pasca amandemen UUD 1945, yang diikuti dengan lahirnya UU No. 24 Tahun 2003 tentang Mahkamah Konstitusi (MK), telah menempatkan hak-hak konstitisional sebagai sesuatu yang sangat fundamental, yaitu dibukanya kesempatan kepada masyarakat untuk melakukan permohonan pengujian UU (judicial review) atas setiap ketentuan UU yang dianggap bertentangan dengan UUD 1945. Perkembangan selanjutnya, ialah dikabulkannya judicial review a quo, maka Perjanjian Perkawinan dapat dilakukan oleh para pihak: sebelum, pada saat dan/atau setelah perkawinan selama disepakati oleh para pihak, selama tidak merugikan pihak ke tiga yaitu pihak-pihak yang terkait dengan harta benda para pihak. ${ }^{4}$

Berdasarkan latar belakang tersebut, penulis akan membahas lebih lanjut pembaharuan hukum di dalam perjanjian pernikahan dalam

${ }^{2}$ Sriyono, Perjanjian Kawin Sebagai Bentuk Perlindungan Terhadap Harta Kekayaan Dalam Perkawinan, Jurnal Ilmiah “Advokasi” Vol. 04. No. 02. September 2016, h. 69.

${ }^{3}$ Yulies Tiena Masriani, Perjanjian Perkawinan dalam Hukum Islam, Jurnal Ilmiah UNTAG "Serat Acitya" Semarang, h. 130.

${ }^{4}$ Yoyon M. Darusman, Kajian Yuridis Pengujian Undang-Undang Pasal 29 Ayat (1), Ayat (3), Ayat (4), Pasal 35 Ayat (1) UU NO. 1 / 1974 Tentang Perkawinan (Studi Pada Putusan MK No. 69/PUU-XIII/2015), Program Pascasarjana Universitas Pamulang, 2016, h. 347-348. 
bentuk Makalah sebagai Ujian Akhir Semester (UAS) dengan judul : "Pembaharuan Hukum di dalam Perjanjian Perkawinan".

\section{B. Pembahasan}

Salah satu aspek penting dalam perkawinan yang diatur dalam Undang-undang Nomor 1 Tahun 1974 Tentang Perkawinan adalah perjanjian perkawinan. Perjanjian perkawinan merupakan istilah yang diambilkan dari judul Bab V Undang-Undang Nomor 1 tahun 1974 tentang Perkawinan yang berisi satu pasal, yaitu pasal 29. Isi selengkapnya dari Bab V, pasal 29 adalah sebagai berikut:

1. Pada waktu atau sebelum perkawinan dilangsungkan, kedua pihak atas persetujuan bersama dapat mengadakan perjanjian tertulis yang disahkan oleh Pegawai pencatat perkawinan, setelah mana isinya berlaku juga terhadap pihak ketiga sepanjang pihak ketiga tersangkut.

2. Perjanjian tersebut tidak dapat disahkan bilamana melanggar batasbatas hukum, agama dan kesusilaan.

3. Perjanjian tersebut mulai berlaku sejak perkawinan dilangsungkan.

4. Selama perkawinan berlangsung perjanjian tersebut tidak dapat dirubah, kecuali bila dari kedua belah pihak ada persetujuan untuk merubah dan perubahan tidak merugikan pihak ketiga.

Dalam Counter Legal Draft juga dicantumkan masalah perjanjian perkawinan, pada Bab V, pasal 21 dan 22. Selengkapnya isi pasal tersebut adalah berikut; Pasal 21, "sebelum perkawinan dilangsungkan, calon suami dan calon isteri dapat mengadakan perjanjian perkawinan tertulis yang disahkan oleh Pegawai Pencatat Perkawinan selama tidak bertentangan dengan undang-undang ini". Pasal 22, "Perjanjian Perkawinan dapat meliputi pembagian harta, perwalian anak, jangka masa perkawinan, dan perlindungan dari kekerasan"

Perjanjian Perkawinan bagi masyarakat Indonesia belum menjadi kebiasaan dan belum menjadi hukum yang hidup di dalam masyarakat, meskipun telah diatur dalam Undang-Undang Perkawinan. Hal ini disebabkan, persoalan perkawinan tidak terlepas dari hukum adat yang hidup di dalam masyarakat Indonesia. Sikap, tindakan, dan perilaku berdasarkan pemikiran hukum adat bahwa perkawinan merupakan ikatan yang sifatnya tidak dapat terpisahkan kecuali maut atas kehendak Tuhan Yang Maha Esa. Sehingga harta yang berkaitan dengan suatu perkawinan tidak bisa dihindarkan dari ketentuan hukum adat. Seiring perkembangan ilmu pengetahuan serta mulai lunturnya pemahaman terhadap perkawinan atas dasar adat, berdampak akan pemahaman di bidang perkawinan, maka hal ini akan berpengaruh 
terhadap pelaksanaan dalam menjalani sebuah perkawinan antara suami dan istri. Berdasarkan hal tersebut telah terjadi banyaknya perkawinan yang tidak berlangsung lama atau antara suami dan istri melakukan perceraian. $^{5}$

Substansi perjanjian perkawinan dalam pasal 29 Undang-Undang Nomor Tahun 1974 tidak mengatur secara tegas bahwa perjanjian perkawinan hanya terbatas pada harta perkawinan, sehingga secara implisit dapat ditafsirkan perjanjian perkawinan tersebut tidak terbatas hanya mengatur mengenai harta perkawinan saja, sepanjang tidak bertentangan dengan norma agama, ketertiban umum dan kesusilaan. Dapat dilihat juga esensi perjanjian perkawinan yang diatur dalam Undang-Undang Nomor Tahun 1974 lebih luas dari pada makna perjanjian perkawinan yang terdapat dalam KUH Perdata (BW). ${ }^{6}$

Secara hukum, perjanjian yang dibuat menimbulkan akibat hukum. Dalam Pasal 29 Undang-Undang Nomor 1 Tahun 1974 Tentang Perkawinan membuka peluang bagi calon pasangan suami istri untuk membuat perjanjian perkawinan. Pasal ini penting, melihat perkembangan sosio-kultural masyarakat Indonesia yang sedang mengalamai proses progresif menuju tatanan masyarakat maju dengan ciri utama kuatnya kesadaran akan hak dan kewajiban. Pada prinsipnya, setiap individu sebagai subjek hukum berhak secara bebas mengadakan perjanjian (contract), kecuali mereka yang belum dewasa atau berada dalam pengampuan. Sepanjang perjanjian tersebut dibuat memenuhi syarat yang ditetapkan oleh peraturan perundang-undangan, maka perjanjian tersebut sah dan berstatus sebagai undang-undang bagi mereka yang membuatnya. ${ }^{7}$

Berdasarkan Undang-Undang Nomor 1 Tahun 1974, isi Perjanjian Perkawinan dapat menyangkut segala sesuatu hal yang tidak bertentangan dengan ketentuan perjanjian secara umum, hanya perjanjian itu disahkan di depan Pegawai Pencatat Nikah. Isi Perjanjian Perkawinan sebagaimana diatur dalam Undang-Undang Nomor 1 Tahun 1974, dapat mengenai segala hal, asal saja tidak melanggar

${ }^{5}$ Sriyono, Perjanjian Kawin Sebagai Bentuk Perlindungan Terhadap Harta Kekayaan Dalam Perkawinan, Jurnal Ilmiah “Advokasi” Vol. 04. No. 02. September 2016, h. 70

${ }^{6}$ Hanafi Arief, Implementasi Yuridis Perjanjian Kawin Dalam Sistem Hukum Positif Di Indonesia, Jurnal Ilmu Hukum "SYARIAH", Volume 15, Nomor 2, Desember 2015, h. 152.

${ }^{7}$ Abdul Rokhim, Kedudukan Hukum Perjanjian Perkawinan Sebagai Alasan Perceraian, jurnal MMH, Jilid 41 No. 1 Januari 2012, h. 59-60. 
batas-batas hukum, agama dan kesusilaan. Adapun isi Perjanjian Perkawinan itu meliputi :

1. Penyatuan harta kekayaan suami istri.

2. Penguasan, pengawasan dan perawatan harta kekayaan istri oleh suami.

3. Istri atau suami melanjutkan kuliah dengan biaya bersama.

4. Dalam perkawinan mereka sepakat untuk melaksanakan keluarga berencana. ${ }^{8}$

\section{Perjanjian Perkawinan Menurut Kitab Undang-Undang Hukum Perdata (Burgelijk Wetbook)}

Perjanjian perkawinan merupakan bagian dari lapangan hukum keluarga yang harus patuh pada ketentuan dalam Buku I Kitab UndangUndang Hukum Perdata (Burgelijk Wetbook $\{\mathrm{BW}\}$ ). Pengaturan perjanjian perkawinan dalam Kitab undang-Undang Hukum Perdata dijelaskan pada Bab VII KUH Perdata pasal 139 s/d 154. Secara garis besar perjanjian perkawinan berlaku mengikat para pihak/mempelai apabila terjadi perkawinan. Berdasarkan Pasal 139 KUH Perdata (BW), keberadaan perjanjian kawin adalah sebagai pengecualian ketentuan Pasal 119 KUH Perdata yaitu ketika perkawinan berlangsung maka secara hukum berlaku persatuan bulat antara kekayan suami maupun kekayaan isteri atau dengan kata lain sebatas mengatur. Pasal 139 KUH Perdata mengandung suatu asas bahwa calon suami istri bebas untuk menentukan isi perjanjian perkawinan yang dibuatnya. Akan tetapi kebebasan tersebut dibatasi oleh beberapa larangan yang harus diperhatikan oleh calon suamiisteri yang akan membuat perjanjian perkawinan. Subtansi perjanjian tidak boleh bertentangan dengan ketertiban umum, kesusilaan, hukum agama. Sebagaimana yang disebutkan dalam Pasal 139 KUHPerdata, bahwa dalam perjanjian perkawinan itu kedua calon suami istri dapat menyimpangi ketentuan-ketentuan yang ditetapkan dalam harta bersama, asal saja penyimpanganpenyimpangan tersebut tidak bertentangan dengan kesusilaan dan ketertiban umum (openbare orde). Menurut Pasal 147 KUH Perdata (BW) bahwa Perjanjian Perkawinan harus dibuat sebelum perkawinan dilangsungkan dan perjanjian tersebut harus dibuat di

8 Filma Tamengkel, Dampak Yuridis Perjanjian Pra Nikah (Prenuptial Agreement) Ditinjau Dari Undang-Undang Nomor 1 Tahun 1974 Tentang Perkawinan, Jurnal Lex Privatum, Vol.III/No. 1/Jan-Mar/2015, h. 200. 
hadapan Notaris, jika tidak dilakukan di hadapan Notaris, maka perjanjian tersebut batal secara hukum. ${ }^{9}$

\section{Perjanjian Perkawinan Menurut Undang-Undang Nomor 1 Tahun 1974 Tentang Perkawinan}

Perjanjian perkawinan merupakan perjanjian tertulis yang dibuat sebelum perkawinan dilangsungkan. Perjanjian perkawinan merupakan istilah ynag diambilkan dari judul Bab V UndangUndang Nomor 1 tahun 1974 tentang yang berisi satu pasal, yaitu pasal 29. Salah satu azas yang terkandung dalam Undang-Undang Nomor 1 tahun 1974 terkait dengan perjanjian perkawinan adalah hak dan kedudukan suami istri yang seimbang (azas equalitas). Menurut azas ini masing-masing pihak dapat melakukan perbuatan hukum secara mandiri. Substansi perjanjian perkawinan dalam pasal 29 Undang-Undang Nomor Tahun 1974 tidak mengatur secara tegas bahwa perjanjian perkawinan hanya terbatas pada harta perkawinan, sehingga secara implisit dapat ditafsirkan perjanjian perkawinan tersebut tidak terbatas hanya mengatur mengenai harta perkawinan saja, sepanjang tidak bertentangan dengan norma agama, ketertiban umum dan kesusilaan. Dapat dilihat juga esensi perjanjian perkawinan yang diatur dalam Undang-Undang Nomor Tahun 1974 lebih luas dari pada makna perjanjian perkawinan yang terdapat dalam KUH Perdata (BW). ${ }^{10}$

a. Bentuk Perjanjian Perkawinan

Bentuk perjanjian perkawinan diatur dalam Pasal 147 Kitab Undang-Undang Hukum Perdata dengan tegas menentukan bahwa perjanjian perkawinan harus dibuat dengan akta notaris, dengan ancaman pembatalan. Syarat ini dimaksudkan agar; Pertama, Perjanjian perkawinan tersebut dituangkan dalam bentuk akta otentik yang mempunyai kekuatan pembuktian yang kuat; Kedua, Memberikan kepastian hukum tentang hak dan kewajiban suami-Isteri atas harta benda mereka, mengingat perjanjian perkawinan mempunyai akibat yang luas. Untuk membuat perjanjian perkawinan dibutuhkan seseorang yang benar-benar menguasai hukum harta perkawinan dan dapat

${ }^{9}$ Hanafi Arief, Implementasi Yuridis Perjanjian Kawin Dalam Sistem Hukum Positif Di Indonesia, Jurnal Ilmu Hukum "Syariah", Volume 15, Nomor 2, Desember 2015, h. 146-149

${ }^{10}$ Hanafi Arief, Implementasi Yuridis Perjanjian Kawin Dalam Sistem Hukum Positif Di Indonesia, Jurnal Ilmu Hukum “Syariah”, h. 149-152 
merumuskan semua syarat dengan teliti. Hal ini berkaitan dengan ketentuan bahwa bentuk harta perkawinan harus tetap sepanjang perkawinan tersebut. Suatu kekeliruan dalam merumuskan syarat dalam perjanjian perkawinan tidak dapat diperbaiki lagi sepanjang perkawinan. ${ }^{11}$

Berbeda dengan Kitab Undang-Undang Hukum Perdata yang mensyaratkan perjanjian perkawinan harus dibuat dengan akta notaris, Undang-Undang Nomor 1 Tahun 1974 dan Kompilasi Hukum Islam hanya mensyaratkan perjanjian perkawinan dibuat dengan bentuk tertulis. Artinya perjanjian perkawinan dapat dibuat sendiri oleh calon suami isteri, hanya saja perjanjian tersebut harus disahkan oleh Pegawai Pencatat Perkawinan pada saat perkawinan dilangsungkan.

b. Isi Perjanjian Perkawinan

Pasal 29 Undang-Undang Nomor 1 Tahun 1974 tentang perkawinan tidak menjelaskan hal-hal apa saja yang dapat diatur dalam suatu perjanjian perkawinan. Batasan yang diberikan hanyalah perjanjian perkawinan tidak boleh melanggar batasbatas hukum, agama dan kesusilaan. Dengan demikian perjanjian perkawinan menurut UndangUndang Nomor 1 Tahun 1974 tidak terbatas pada masalah harta perkawinan saja, tetapi dapat juga mengatur mengenai hal lain.

Isi perjanjian tidak diatur oleh undang-undang perkawinan. Isi dari perjanjian adalah hak dari suami dan istri, mereka bebas menentukan isi dari perjanjian yang akan mereka tentukan, namun isi perjanjian harus sesuai koridor hukum, agama, dan kesusilaan.

Asas kebebasan kedua belah pihak dalam menentukan isi perjanjian kawinnya dibatasi oleh ketentun-ketentuan sebagai berikut:

a. Tidak membuat janji-janji (bedingen) yang bertentagan dengan kesusilaan dan ketertiban umum.

b. Perjanjian kawin tidak boleh mengurangi hak-hak karena kekuasaan suami, hak-hak karena kekuasaan orang tua, hakhak suami-istri yang hidup terlama.

11 Annisa Istrianty dan Erwan Priambada, Akibat Hukum Perjanjian Perkawinan Yang Dibuat Setelah Perkawinan Berlangsung, Jurnal Privat Law Vol. III No 2 Juli-Desember 2015, h. 78. 
Jamaluddin

c. Tidak membuat janji yang mengandung pelepasan hak atas peninggalan.

d. Tidakdibuat janji-janji,bahwa salah satu pihak akan memikul hutang lebih besar.

e. Tidak dibuat janji-janji, bahwa harta perkawinan akan diatur oleh undang-undang Negara asing.

Kaitan antara syarat dalam perkawinan dengan perjanjian perkawinan adalah karena perjanjian itu berisi syarat-syarat yang harus dipenuhi oleh pihak yang melakukan perjanjian dalam arti pihak-pihak yang berjanji untuk memenuhi syarat yang ditentukan. Syarat atau perjanjian yang dimaksud ini dilakukan diluar prosesi akad perkawinan. Oleh karena itu perjanjian perkawinan terpisah dari akad nikah, maka tidak ada kaitan Hukum antara akad nikah yang dilaksanakan secarah sah dengan pelaksanaan syarat yang ditentuka diperjanjian itu. Hal ini berarti bahwa tidak dipenuhinya perjanjian tidak menyebabkan batalnya nikah yang sudah sah. Apabilah didalam ijab qabul diiringi dengan suatu syarat, baik itu syarat itu masih termasuk dalam rangkaian pernikahan, atau menyalahi hukum pernikahan atau mengandung manfaat yang akan diterimah atau mengandung syarat yang dilarang agama. Maka masing-masing syarat tersebut mempunyai ketentuan hukum tersendiri.

\section{Macam-Macam Perjanjian Perkawinan}

Para calon suami-istri dapat memperjanjikan segala bentuk pengecualian atas persatuan atas harta kekayaan (secara bulat) yang diinginkan, antara lain dapat diatur perjanjian pisah harta sama sekali dan perjanjian perkawinan yang merupakan campuran kekayaan secara terbatas (beperkte gemeenschap van goerderen) yaitu persatuan untung dan rugi (gemenschap van winst en verlies) dan persatuan hasil dan pendapatan (gameesnschap van vruchten en inskomsten), yaitu, ${ }^{12}$

Pertama, Pisah Harta Sama Sekali. Di Indonesia kebanyakan orang kawin dengan kebersamaan harta (tanpa perjanjian perkawinan) atau apabila dibuat perjanjian perkawinan meniadakan sama sekali kebersamaan harta. Sehingga di dalam praktek,

12 Annisa Istrianty dan Erwan Priambada, Akibat Hukum Perjanjian Perkawinan Yang Dibuat Setelah Perkawinan Berlangsung, Jurnal Privat Law Vol. III No 2 Juli-Desember 2015, h. 89. 
perjanjian perkawinan yang banyak diadakan adalah yang meniadakan sama sekali persatuan harta kekayaan. Menurut Pasal 144 Kitab UndangUndang Hukum Perdata untuk meniadakan sama sekali persatuan harta kekayaan, yaitu menghendaki agar harta mereka sepanjang perkawinan terpisah sama sekali, maka para pihak di dalam perjanjian kawin harus menyatakan, bahwa antara mereka calon suami itu secara tegas-tegas menyatakan bahwa mereka juga tidak menghendaki adanya persatuan untung dan rugi. Berdasarkan perjanjian perkawinan tersebut, maka masing-masing suamiistri tetap menjadi pemilik dari barangbarang suami-istri tetap menjadi pemilik dari barang-barang yang mereka bawa ke dalam perkawinan dan di samping itu karena setiap bentuk kebersamaan atau persatuan telah mereka kecualikan, maka hasil yang mereka peroleh sepanjang perkawinan baik yang berupa hasil usaha, maupun hasil yang keluar dari harta milik pribadi mereka, tetap menjadi milik pribadi masingmasing suami-istri yang bersangkutan. Dengan demikian dalam perjanjian ini hanya ada dua kelompok harta dalam perkawinan yaitu harta kekayaan pribadi suami dan harta kekayaan pribadi istri.

Kedua, Persatuan Untung dan Rugi (gemenschap van winst en verlies). Ketentuan mengenai persatuan untung dan rugi ini diatur dalam Pasal 155 KUHPerdata yang mengatakan sebagai berikut; "Jika dalam perjanjian perkawinan oleh kedua calon suami istri hanyalah diperjanjikan bahwa dalam persatuan perkawinan meraka akan berlaku persatuan untung dan rugi, maka beartilah perjanjian yang demikian, bahwa, dengan sama sekali tak berlakunya persatuan harta kekayaan seluruhnya menurut undang-undang, setelah berakhirnya persatuan suamiistri, segala keuntungan pada mereka, yang diperoleh sepanjang perkawinan, harus dibagi antara mereka berdua, seperti pun segala kerugian harus mereka pikul berdua pula". Jadi, bila dijanjikan persatuan tersebut, maka semua keuntungan yang diperoleh dan semua kerugian yang diderita sepanjang perkawinan menjadi bagian dan bebas suami-istri menurut perbandingan yang sama besarnya yaitu satu berbanding satu $(1: 1)$. Untuk sedapat mungkin mencegah adanya kesulitan pembuktian dikemudian hari, maka benda-benda tak terdaftar harus diperincikan dengan jelas, di dalam perjanjian perkawinan yang bersangkutan, atau didalam suatu laporan yang ditandatangani suamiistri dihadapan Notaris, dilampirkan dalam perjanjian perkawinan yang bersangkutan (Pasal 165 Kitab UndangUndang Hukum Perdata). 
Ketiga, Perjanjian Persatuan dan Pendapatan ( gemeenschap van vruchten eninkomsten). Peraturan dalam Kitab UndangUndang Hukum Perdata yang mengatur perjanjian perkawinan dengan kebersamaan atau persatuan penghasilan dan pendapatan hanya ada satu pasal saja yaitu Pasal 164 Kitab Undang-Undang Hukum Perdata, mengatakan sebagai berikut: "Perjanjian, bahwa antara suamiistri hanya akan berlaku persatuan hasil dan pendapatan, berati diam-diam suatu ketiadaan persatuan harta kekayaan seluruhnya menurut undang-undang, dan ketiadaan persatuan untung dan rugi”. Berdasarkan ketentuan pasal tersebut, maka dalam perjanjian ini hanya berlaku apa yang pada persatuan untung dan rugi dianggap sebagai keuntungan menjadi percampuran tetapi penanggungan kerugian bersama, sama sekali tidak ada, kerugian hanya menjadi tanggungan suami. Isteri bertanggung jawab atas hutang-hutang yang timbul dari pihaknya. Pada pemecahan, isteri juga dapat melepaskan pencampuran, tetapi hal ini tidak mempunyai banyak arti, karena dengan tidak usah melepaskan percampuran, isteri juga tidak ikut membayar dengan harta pribadinya apabila ada kerugian. Didalam perjanjian ini juga ada tiga macam harta kekayaan, yaitu harta pribadi suami, harta pribadi istri dan harta persatuan.

\section{Harta Perkawinan Menurut Kompilasi Hukum Islam (KHI)}

Di dalam Kompilasi Hukum Islam (KHI) mengenai harta bersama diatur dalam Bab XII tentang Harta Kekayaan dalam perkawinan pada Pasal 85 sampai dengan Pasal 97. Pasal 85 menyatakan bahwa: adanya harta bersama dalam perkawinan itu tidak menutup kemungkinan adanya harta milik masing-masing suami atau isteri. Sedangkan asal usul/jenis harta bersama dalam perkawinan menurut Pasal 91 adalah sebagai berikut:

a. Harta bersama sebagaimana tersebut dalam Pasal 85 berupa benda berwujud atau tidak berwujud;

b. Harta bersama yang berwujud dapat meliputi benda tidak bergerak, benda bergerak, dan surat-surat beharga;

c. Harta bersama yang tidak berwujud dapat berupa hak maupun kewajiban;

d. Harta bersama dapat dijadikan sebagai barang jaminan oleh salah satu pihak atas persetujuan pihak lainnya.

Mengenai pengaturan pengalihan harta kekayaan secara tegas terdapat dalam Pasal $92 \mathrm{KHI}$ yang menyebutkan bahwa suami atau isteri tanpa persetujuan pihak lain tidak diperbolehkan menjual atau 
memindahkan harta bersama. Artinya pengurusan harta perkawinan dilakukan secara bersama-sama oleh suami isteri. Apabila salah satu pihak akan melakukan sesuatu yang berkaitan dengan harta bersama tersebut, harus mendapat persetujuan dari pihak isteri.

Berikutnya dalam Pasal 94 KHI menyebutkan bahwa harta bersama dari perkawinan dari seorang suami yang mempunyai isteri lebih dari seorang, masing-masing terpisah dan berdiri sendiri dan pemilikan harta bersama dari perkawinan seorang suami yang mempunyai isteri lebih dari seorang, dihitung pada saat berlangsungnya perkawinan yang kedua, ketiga atau yang keempat.

Dalam hubungannya dengan berakhirnya pengurusan harta perkawinan menurut KHI, pada saat perkawinan berakhir, maka pengurusan harta bersama pun ikut berakhir. Ini dapat dipahami, karena pengertian harta perkawinan adalah harta yang diperoleh selama perkawinan, baik itu harta yang dihasilkan kedua belah pihak dalam perkawinan, harta yang dibawa ke dalam perkawinan. Untuk itu dengan terjadinya kematian, secara otomatis tidak ada lagi harta benda perkawinan, karena perkawinan itu sendiri sudah tidak ada, sehingga pengurusan harta bersama pun akan berkahir dengan sendirinya. Memperhatikan pasal-pasal tersebut di atas, yang dianggap sebagai harta bersama adalah berupa benda milik suami isteri yang mempunyai nilai ekonomi dan hukum.

Harta bersama dapat berupa benda berwujud yang meliputi benda bergerak dan tidak bergerak serta harta bersama berbentuk surat-surat beharga dan harta bersama berupa benda tidak berwujud berupa hak dan kewajiban. Dalam literature hukum, "benda adalah terjemahan dari istlah bahasa Belanda zaak, barang adalah terjemahan dari goog dan hak adalah terjemahan dari recht. Menurut Pasal 499 KUHPerdata, Pengertian Benda meliputi barang dan hak. Barang adalah benda berwujud sedangkan hak adalah benda tak berwujud. Pada benda melekat suatu hak. Setiap pemilik benda adalah juga pemilik hak atas bendanya itu. Hak atas benda milik tersebut hak milik yang disingkat dengan milik saja.

Dalam hukum Islam Harta Kekayaan dalam perkawinan (syirkah) diatur dalam Inpres No. 1 Tahun 1991 pasal 1 huruf f, mengatakan bahwa harta kekayaan dalam perkawinan atau Syrkah adalah harta yang diperoleh sendiri-sendiri atau bersama-sama suami isteri selama dalam perkawinan berlangsung dan selanjutnya disebut harta bersama tanpa mempersoalkan terdaftar atas nama siapa. Jadi mengenai harta yang diperoleh oleh suami isteri selama dalam ikatan 
perkawinan adalah harta milik bersama, baik masing-masing bekerja pada satu tempat yang sama maupun pada tempat yang berbedabeda, baik pendapatan itu terdaftar sebagai penghasilan isteri atau suami, juga penyimpanannya didaftarkan sebagai simpanan suami atau isteri tidak dipersoalkan, baik yang punya pendapatan itu suami saja atau isteri saja, atau keduanya mempunyai penghasilan tersendiri selama dalam perkawian. ${ }^{13}$

\section{Pembaharuan Hukum di Dalam Perjanjian Perkawinan Pasca Putusan Mahkamah Konstitusi Nomor 69/PUU-XIII/2015}

Dengan adanya putusan a quo Mahkamah Konstitusi (MK) Nomor 69/PUU-XIII/2015, pasangan suami istri yang belum memiliki perjanjian perkawinan sebelum perkawinan dilangsungkan dapat melakukan perjanjian perkawinan pada saat perkawinan telah dilaksanakan. Perjanjian perkawinan tersebut harus dibuat atas persetujuan bersama, dengan perjanjian tertulis yang disahkan oleh Petugas Pencatat Perkawinan, sebelum perkawinan itu berlangsung atau pada saat perkawinan berlangsung dan perjanjian perkawinan tersebut mulai berlaku sejak perkawinan itu dilangsungkan. Perjanjian semacam ini biasanya berisi janji tentang harta benda yang diperoleh selama perkawinan berlangsung, lazimnya berupa perolehan harta kekayaan terpisah, masing-masing pihak memperoleh apa yang diperoleh atau didapat selama perkawinan itu termasuk keuntungan dan kerugian. Perjanjian perkawinan ini berlaku sebagai undang-undang bagi mereka yang membuatnya, juga berlaku bagi pihak ketga yang memiliki kepentngan terhadapnya. Menurut Pasal 29 Undang-Undang Nomor 1 Tahun 1974, Perjanjian Perkawinan dapat dibuat pada waktu atau sebelum perkawinan dilangsungkan. Selama ini sesuai dengan Pasal 29 Undang-Undang Nomor 1 Tahun 1974, perjanjian yang demikian itu harus diadakan sebelum perkawinan dilangsungkan dan harus diletakkan dalam suatu akta notaris. Perjanjian perkawinan ini mulai berlaku antara suami dan isteri sejak perkawinan dilangsungkan. Isi yang diatur di dalam perjanjian perkawinan tergantung pada kesepakatan pihak-pihak calon suami dan isteri, asal tidak bertentangan dengan undang-undang, agama, dan kepatutan atau

${ }^{13}$ Ria Desviastanti, Perlindungan Hukum Terhadap Harta Dalam Perkawinan Dengan Pembuatan Akta Perjanjian Kawin, (Program Pascasarjana Universitas Diponegoro: Semarang, 2010), h. 68-70 
kesusilaan. Adapun terhadap bentuk dan isi perjanjian perkawinan, kepada kedua belah pihak diberikan kebebasan atau kemerdekaan seluas-luasnya (sesuai dengan asas hukum "kebebasan berkontrak"). Putusan MK tersebut juga menegaskan asas nasionalitas dalam kepemilikan tanah dan bangunan di Indonesia. Dengan demikian, meskipun terdapat peluang untuk adanya perjanjian perkawinan dibuat kapanpun dan oleh siapapun kewarganegaraannya, tetapi muatan perjanjian perkawinan tersebut terbatas terkait dengan kepemilikan tanah dan bangunan. Sehingga pasangan suami istri yang berkewarganegaraan asing tetap tdak bisa memiliki hak milik atau hak guna bangunan dengan alasan apapun. Apabila dalam perjanjian perkawinan terdapat klausul yang memungkinkan menyebabkan pasangan suami atau istri yang berbeda kewarganegaraan dan dimungkinkan pasangan yang berwarga negara asing mendapatkan kepemilikan atas tanah dan bangunan di Indonesia, maka perjanjian itu batal demi hukum. ${ }^{14}$

\section{Akibat Hukum Perjanjian Perkawinan}

Sebagaimana akibat hukum dari perkawinan yang sah, maka perjanjian perkawinan yang dibuat setelah perkawinan juga sudah pasti akan menimbulkan akibat hukum baik terhadap pihak yang membuatnya, terhadap harta benda, maupun terhadap pihak ketiga yang terkait, yaitu: ${ }^{15}$

Pertama, akibat hukum terhadap pihak yang membuatnya Pembuatan perjanjian perkawinan setelah perkawinan adalah merupakan persetujuan dan kesepakatan dari kedua belah pihak suami istri untuk membuat perjanjian perkawinan setelah perkawinan ini berlaku dan mengikat bagi kedua belah pihak yang membuat perjanjian tersebut. Hal ini sesuai dengan ketentuan dalam Pasal 1338 KHUPerdata yang berbunya : "semua perjanjian yang dibuat secara sah berlaku sebagai undang-undang bagi mereka yang membuatnya." Perjanjian kawin setelah perkawinan ini terbentuk karena adanya persetujuan dan tercapainya kata sepakat antara para pihak yang membuatnya. Yang dalam hal ini adalah para pemohon

${ }^{14}$ Oly Viana Agustne, Politik Hukum Perjanjian Perkawinan Pasca Putusan Mahkamah Konstitusi Nomor 69/PUU-XIII/2015 Dalam Menciptakan Keharmonisan Perkawinan, Jurnal Rechtsvinding, Volume 6, Nomor 1, 2017, h. 59-62

15 Ahmad Royani, Perjanjian Kawin Yang Dibuat Setelah Perkawinan Terhadap Pihak Ketiga (Pasca Putusan Mahkmah Konstitusi Nomor 69/PUUXIII/2015), Jurnal Independent Vol 5 No. 2, h. 12-13 
atau suami istri, sehingga dengan sendirinya perjanjian perkawinan ini juga mengikat secara hukum bagi para pihak yang membuatnya saat keduanya sepakat tentang perjanjian perkawinan tersebut untuk memenuhi kesepakatan yang terdapat dalam perjanjian perkawinan tersebut.

Kedua, akibat hukum terhadap harta benda kekayaan Setelah adanya perjanjian perkawinan maka harta benda masing-masing pihak suami istri akan menjadi semakin kuat pula secara hukum. Masing-masing pihak suami maupun istri harus mematuhi segala isi perjanjian perkawinan tersebut sebab segala hal yang menyangkut pemisahan harta sudah jelas dipisahkan, juga terhadap harta-harta lain yang kemudian hari timbul setelah tanggal perjanjian tersebut tetap terpisah satu dengan yang lainnya, sehingga tidak ada lagi berstatus harta bersama. Sebagaimana yang dinyatakan dalam Pasal 164 KUHPerdata bahwa apabila dijanjikan suatu persatuan hasil dari pedapatan, mata tidak akan terjadi persatuan harta kekayaan secara bulat dan persatuan untung rugi. Demikian juga halnya dengan hutang piutang yang ditimbulkan akibat perbuatan hukum dari pasangan hidupnya yang dilakukan setelah perjanjian perkawinan menjadi tanggung jawab dari pasangan hidupnya. Sehingga adanya perjanjian perkawinan ini dapat melindungi secara hukum harta benda kekayaan yang dimiliki oleh masing-masing pihak suami istri.

Ketiga, akibat hukum terhadap pihak ketiga Berlakunya perjanjian perkawinan juga akan berakibat hukum terhadap pihak ketiga yang berkaitan dengannya, sesuai dengan ketentuan Pasal 147 juncto Pasal 157 KUHPerdata bahwa sejak perkawinan dilangsungkan perjanjian perkawinan hanya berlaku bagi para pihak yang membuatnya yaitu pasangan suami istri, sedangkan perjanjian perkawinan baru berlaku terhadap pihak ketinga sejak didaftarkan di Pegawai Pencatat Perkawinan atau Kantor Catatan Sipil. Pembuatan perjanjian perkawinan yang hubungannya terhadap pihak ketiga akan berlaku sejak tanggal didaftarkannya ke Kantor Catata Sipil atau Pegawai Pencatat Perkawinan. Sehingga pihak ketiga dalam hal ini tidak dirugikan jika terjadi sesuatu dikemudian hari, karena sudah ada kesepakatan pemisahan harta sebelumnya. Namun jika pihak ketiga (kreditur) bisa membuktikan bahwa yang dijadikan jaminan hutang atau diperjanjikan sebagai jaminan dalam bentuk apapun diperoleh sebelum didaftarkannya ke pegawai pencatat perkawinan maka pihak ketiga dapat menuntut pelunasannya terhadap harta bersama suami istri. Sedangkan utang yang dibuat 
oleh salah satu pihak suami atau istri setelah dicatat oleh pegawai pencatat perkawinan tersebut maka pihak ketiga dapat ditagih pelunasannya terhadap pihak suami atau pihak istri yang berhutang.

\section{Penutup}

Indonesia memasuki era di mana perjanjian perkawinan sudah mulai dibutuhkan, terutama di kota-kota besar. Karena itu, UndangUndang No. 1 Tahun 1974 Tentang Perkawinan perlu menyesuaikan dengan perkembangan masyarakat itu. Di antara perkembangan hukum itu adalah dengan lahirnya putusan MK No. 69/PUU-XIII/2015. Dengan pembaharuan hukum yang dilakukan MK ini, pasutri bisa melakuukan perjanjian perkawinan selama di dalam ikatan suami istri. Konsekuensi dari perjanjian perkawinan itu juga berpengaruh terhadap pihak ketiga. Tetapi, pengaruh itu dibatasi peraturan lain agar tidak menimbulkan kerugian.

\section{Daftar Pustaka}

Abdul Rokhim, Kedudukan Hukum Perjanjian Perkawinan Sebagai Alasan Perceraian, jurnal MMH, Jilid 41 No. 1 Januari 2012. Ahmad Royani, Perjanjian Kawin Yang Dibuat Setelah Perkawinan Terhadap Pihak Ketiga (Pasca Putusan Mahkmah Konstitusi Nomor 69/PUU-XIII/2015), Jurnal Independent Vol 5 No. 2.

Annisa Istrianty dan Erwan Priambada, Akibat Hukum Perjanjian Perkawinan Yang Dibuat Setelah Perkawinan Berlangsung, Jurnal Privat Law Vol. III No 2 Juli-Desember 2015.

Filma Tamengkel, Dampak Yuridis Perjanjian Pra Nikah (Prenuptial Agreement) Ditinjau Dari Undang-Undang Nomor 1 Tahun 1974 Tentang Perkawinan, Jurnal Lex Privatum, Vol.III/No. 1/Jan-Mar/2015.

Hanafi Arief, Implementasi Yuridis Perjanjian Kawin Dalam Sistem Hukum Positif Di Indonesia, Jurnal Ilmu Hukum "SYARIAH", Volume 15, Nomor 2, Desember 2015.

Oly Viana Agustne, Politik Hukum Perjanjian Perkawinan Pasca Putusan Mahkamah Konstitusi Nomor 69/PUU-XIII/2015 Dalam Menciptakan Keharmonisan Perkawinan, Jurnal Rechtsvinding, Volume 6, Nomor 1, 2017.

Ria Desviastanti, Perlindungan Hukum Terhadap Harta Dalam Perkawinan Dengan Pembuatan Akta Perjanjian Kawin, (Program Pascasarjana Universitas Diponegoro: Semarang, 2010) 
Jamaluddin

Sriyono, Perjanjian Kawin Sebagai Bentuk Perlindungan Terhadap Harta Kekayaan Dalam Perkawinan, Jurnal Ilmiah "Advokasi”" Vol. 04. No. 02. September 2016.

Undang-Undang No. 1 Tahun 1974 Tentang Perkawinan

Yoyon M. Darusman, Kajian Yuridis Pengujian Undang-Undang Pasal 29 Ayat (1), Ayat (3), Ayat (4), Pasal 35 Ayat (1) UU NO. $1 /$ 1974 Tentang Perkawinan (Studi Pada Putusan MK No. 69/PUU-XIII/2015), Program Pascasarjana Universitas Pamulang, 2016.

Yulies Tiena Masriani, Perjanjian Perkawinan dalam Hukum Islam, Jurnal Ilmiah UNTAG "Serat Acitya” Semarang. 